\title{
Detection of Multidrug Resistance and Characterization of Mutations in Mycobacterium tuberculosis Isolates in Raichur District, India
}

\author{
Akshay Kumar Arya ${ }^{1 *}$, R. Venkatesh Naik ${ }^{1}$, K.V. Arjun ${ }^{2}$ and B.V. Peerapur ${ }^{1}$ \\ ${ }^{1}$ Department of Microbiology, RIMS, Raichur, Karnataka, India \\ ${ }^{2}$ Microbiologist \& Incharge DST Lab, Dept. of Microbiology, RIMS, Raichur, Karnataka, India \\ *Corresponding author
}

\section{A B S T R A C T}

Tuberculosis remains as one of the leading cause of morbidity and mortality globally. Estimated cases of around 9.6 million are affected by all forms of TB worldwide, out of

Keywords

MDR-TB, Drug resistance, Line probe assay, Rifampicin and Isoniazid, Drug susceptibility testing.

Article Info

Accepted:

14 September 2017

Available Online:

10 October 2017 which 2.2 billion are affected in India. India also has the second highest burden of MDR TB after China. Information on MDR TB is sparse in Raichur District. We undertook this study to detect MDR TB among MDR suspected cases and its common mutation using Genotype MTBDR plus. All presumptive MDR sputum samples were sent to DST LAB RIMS, Raichur from various part of Raichur district. Samples in study were taking during the period from January 2017 to April 2017. Line Probe Assay was done on sputum samples to detect common mutations in $r p o \mathrm{~B}$ gene for Rifampicin and kat $\mathrm{G}$ gene and inh $\mathrm{A}$ gene for Isoniazid resistance respectively. Out of the 448 samples received from MDR suspects, 49(10.9\%) were found to be MDR TB. Commonest pattern for Rifampicin resistance was missing WT8 probe along with mutation in MUT3 band (S531L) codon, and mutation of MUT1 band (S5315T) of katG gene was commonest pattern for Isoniazid resistance. The MDR-TB among presumptive MDR in Raichur district was found to be $10.9 \%$, and the mutation pattern obtained for Rifampicin and Isoniazid resistance were similar to those reported earlier.

\section{Introduction}

TB in India is an ancient disease, and in Indian literature it has been mentioned that it occurred from around $1500 \mathrm{BCE}$. But at the beginning of the nineteenth century it was generally thought that there was hardly any TB occurring in India, so it was the least area of concern, It was in The second All-India Sanitary Conference, Madras 1912, due to increase mortality caused by TB there was discussion of $\mathrm{TB}$ and different views were expressed to the measures that should be taken. Like formation of anti-tuberculosis societies, the establishment of more sanatoria, the establishment of dispensaries, the improved ventilation of homes and schools, as well as the use of tuberculin ${ }^{1}$. Scenario has changed now in regard to TB.

According to WHO report in 2015, there were an estimated 10.4 million new (incident) TB cases worldwide Six countries accounted for $60 \%$ of the new cases: India, Indonesia, China, Nigeria, Pakistan and South Africa. ${ }^{2}$

In MDR TB are resistance to Rifampicin, with or without resistance to other $\operatorname{drugs}^{2}$, 
XDR is defined as resistance to Rifampicin and Isoniazid as well as any member of Quinolone and at least one of the second line anti TB injectable drugs.

In 2015, there were an estimated 4,80,000 new cases of multidrug-resistant TB (MDRTB). ${ }^{2}$

India, China and the Russia accounted for $45 \%$ of the combined total of 5,80,000 cases. India has second highest TB burden MDRTB rates have been found to be 17.4 to 53 per cent among previously treated cases who are more likely to develop multi-drug resistance. Reportedly first case of XDRTB is also detected in India in November 2011. ${ }^{(3,4,5)}$

This kind of rapid progression of drug resistance from MDR to XDR and XXDR TB underline the needs for rapid and accurate diagnosis of drug resistance TB. Newer diagnostic tests like Cartridge Based Nucleic Acid Amplification Test (CB-NAAT), MGIT 960 and Line Probe Assay (LPA) are some of the tests for the diagnosis of tuberculosis rapid detection of RIF and INH resistance. XDR was first reported in 2006, since then it has spread to 6 continent and 55 countries ${ }^{(2)}$. This kind of rapid progression of drug resistance from MDR to XDR and XXDR TB underline the needs for rapid and accurate diagnosis of drug resistance TB.

The diagnosis of MDR TB is based on isolation of strain resistance to medicines. Newer diagnostic tests like Cartridge Based Nucleic Acid Amplification Test (CBNAAT), MGIT 960 and Line Probe Assay (LPA) are some of the tests for the diagnosis of tuberculosis and rapid detection of RIF and INH resistance.

The data for MDR TB is sparse in this region of the state due to lack of proper infrastructure and training, Hence we have undertaken this study for detection of MDR
TB and common mutation among MDR suspects using Line Probe Assay, this study could be useful for strategic planning and control of MDR TB in this region of state.

\section{Materials and Methods}

All presumptive MDR patients' sputum samples were collected during the period from January 2017 to April 2017 to DST LAB Department of Microbiology, RIMS Raichur.

\section{MDR suspect criteria includes}

Failure

Re-treatment cases sputum positive at $4^{\text {th }}$ months.

Sputum positive cases at diagnosis, retreatment cases.

Any follow up sputum positive

Sputum negative at diagnosis, re-treatment case

HIV TB cases Line Probe Assay was done on these suspected samples

\section{Sample preparation and processing ( $\mathrm{NaCl}$ - $\mathrm{NaOH}$ method)}

All the sample preparation and processing was done in BSL 3 laboratory. The samples were processed using the working solution of $50 \mathrm{ml}$ of $4 \%$ Sodium hydroxide $(\mathrm{NaOH})+50$ $\mathrm{ml}$ of $2.9 \%$ Sodium citrate $+500 \mathrm{mg}$ of NALC powder.

DNA extraction was done using Lysis A and Neutralizing Buffer, One part used for amplification and rest was stored at -20 degree C. Master mix was prepared using the reagent provided in the kit 5microlitre DNA was added to 45 microlitre of master mix 
solution Then DNA Amplification and Hybridization was carried out per manufactures instruction DNA extraction, Master mix preparation, DNA amplification and Hybridization all were carried out in separate designated rooms and unidirectional workflow was maintained. The results of DNA strips were interpreted with the help of reporting card (Fig. 2). The absence or presence of wild type and mutant band were recorded.

\section{Results and Discussion}

Out of 448 samples in which Line Probe Assay was performed (Fig. 1), Resistance to both Rifampicin and Isoniazid was found in $33 / 448(7.36 \%)$ isolates, mono resistance to Rifampicin was found in 16/448 (3.6\%) isolates, and mono resistance to Isoniazid was found in 31 (6.9\%) isolates, Total Rifampicin resistance was found to be 49/448 (10.9\%). Remaining $368(82.2 \%)$ isolates out of 448 were found to be susceptible to both Rifampicin and Isoniazid.

Among 49 total Rifampicin resistance isolates, missing wild type (WT) probe with known mutation was found in 29/49 (59.1\%) isolates, $r p o \mathrm{~B}$ WT8(531-533) was the commonest wild type probe missing $(25 / 29,86.2 . \%)$ followed by WT7(3/29,10.3\%) and WT1(1/29) (Table 1).

Commonest Rifampicin mutation in these strains was in S531L codon $(25 / 29,86.2 \%)$ followed by mutation in H526Y codon $(2 / 29$, $6.8 \%$ ), then in H526D and D516V codon both having $1 / 29(3.4 \%)$ mutation (Table 2). In 6/49(12.4\%) Rifampicin resistance strains, one or more wild type (WT) probes were missing with no mutation band found in them. In 5/49(10.3\%) Rifampicin resistance strain, one or more wild type probe was missing with mutation band found on them. WT3/WT4 were the most common wild type band missing in these type was strain (5/49).Mixed pattern of Rifampicin resistance in which all wild type (WT) of probe were present along with the presence of one or more mutant band was present in $8 / 49(16.3 \%$ ) isolates (Table 1), MUT3(S531L) was the most common mutation present $(7 / 8,87.5 \%)$ followed by MUT1(1/8,12.5\%) (Table 2).

Out of 448 samples total of 64(14.2\%) Isoniazid resistant isolates were detected. Missing wild type kat GWT1 was most common probe missing with known mutation 42/64 (65.6\%) (Table 3), most common mutation in kat $\mathrm{G}$ was found in MUT1 band (S315T1 codon) in 42/42(100\%) strains.

In $2 / 64(3.1 \%)$ strains of Isoniazid resistance wild type katGWT1 probe was missing with no mutation band (Table 3), mixed kat G resistance was found in 6/64(9.3\%) samples with MUT1 band (S315T1 codon) mutation in 6/6 (100\%) strains (Table 4) inhA gene with missing wild type probe inhAWT1 with known mutation was found in 9/64(14.5\%) (Table 3), 9/9(100\%) inhA MUT1 band C15T codon was most common mutation present in these strain. with missing wild type which included 14/14 (100\%) mutation inhA MUT1 in $\mathrm{C} 15 \mathrm{~T}$ codon. Both inh $\mathrm{A}$ and $k a t \mathrm{G}$ mutation was found in $2 / 64(3.1 \%)$. Mixed pattern of Isoniazid resistance was found in $1 / 64(1.6 \%)$ isolates (Table 4).

Out of total 448 isolates $49(10.9 \%)$ were found to be MDR TB, Commonest pattern for Rifampicin resistance was missing WT8 probe with mutation in codon S531L being most common and missing of katG gene was commonest pattern for Isoniazid resistance with mutation in S53T1 was most common.

Similar study was done by Ritu Singhal et al., in Northeast state of India during the period of January 2012 to august 2012, in which from total of 553 sputum samples, 181 (32.7\%) isolates were found to be multidrug resistant. Missing WT8 along with mutation 
in codon S531L was commonest pattern for Rifampicin resistant isolates $(65.1 \%)$ and missing WT along with mutations in codon
S315T1 of katG gene was commonest pattern for Isoniazid resistant isolates $(86.2 \%){ }^{(6)}$

Fig.1 Methodology of line probe assay

DNA isolated from the processed sputum samples<smiles>C1CCC1</smiles>

PCR of Mycobacterium DNA using biotin labeled primers<smiles>C1CCC1</smiles>

Denaturation of amplified DNA product in single strands<smiles>C1CCCC1</smiles>

Hybridization of denatured DNA<smiles>C1CCC1</smiles>

Enzyme mediated detection of bands where DNA products have bound to the strip

Fig.2 Reporting card for line probe assay

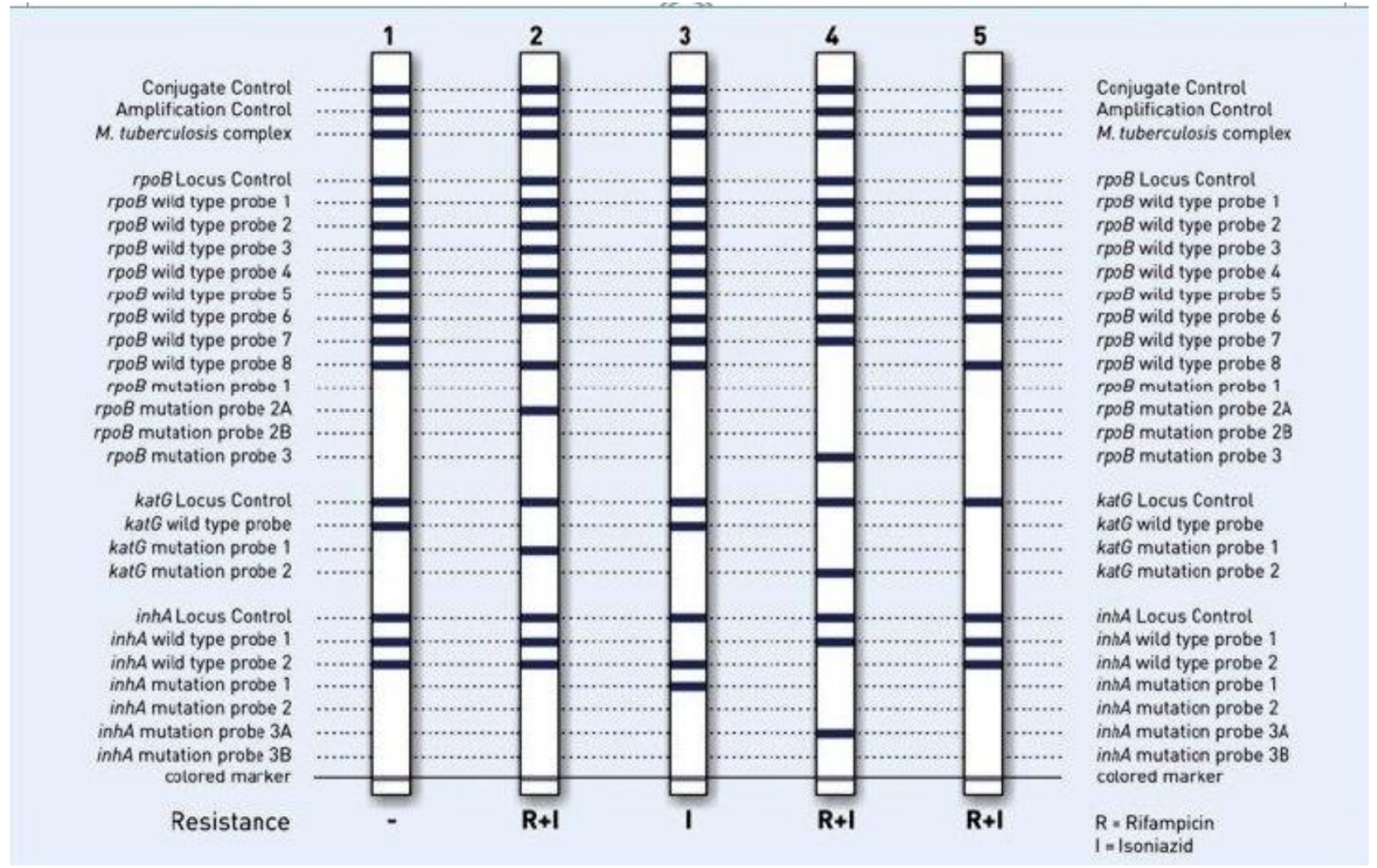


Table.1 Missing wild type of probe for Rifampicin resistance.

Total Rifampicin resistance isolates (n-49)

\begin{tabular}{|l|l|l|l|l|}
\hline GENE & $\begin{array}{l}\text { BAND } \\
\text { MISSING }\end{array}$ & $\begin{array}{l}\text { MISSING WILD TYPE } \\
\text { BAND WITH KNOWN } \\
\text { MUTATION n-29 }\end{array}$ & $\begin{array}{l}\text { ONE OR MORE MISSING } \\
\text { WILD TYPE BAND WITH } \\
\text { NO MUTANT PROBE } \text { n-6 }\end{array}$ & $\begin{array}{l}\text { ONE OR MORE MISSING } \\
\text { WILD TYPE BAND WITH } \\
\text { MUTANT PROBE } \text { n-5 }\end{array}$ \\
\hline $\boldsymbol{r p o B}$ & WT1 & 01 & 00 & 00 \\
\hline & WT2 & 00 & 02 & 00 \\
\hline & WT3 & 00 & 02 & 05 \\
\hline & WT4 & 00 & 01 & 05 \\
\hline & WT5 & 00 & 01 & 00 \\
\hline & WT6 & 00 & 00 & 00 \\
\hline & WT7 & 03 & 02 & 00 \\
\hline & WT8 & 25 & 02 & 00 \\
\hline
\end{tabular}

Table.2 Mutation pattern in Rifampicin resistance. Total Rifampicin resistance isolates (n-49)

\begin{tabular}{|l|l|l|l|l|}
\hline MUTATION PRESENT & IN MISSING & IN ONE OR MORE & IN ONE OR MORE & MIXED \\
& WILD TYPE & WILD TYPE & WILD TYPE \\
WITH KNOWN & MISSING WITH \\
& MUTATION n- & MUTANT PROBE \\
PRESENT n-5 & $\begin{array}{l}\text { MUTANT PROBE } \\
\text { ABSENT n-6 }\end{array}$ & $\begin{array}{l}\text { RESISTANCIN } \\
\text { n-8 }\end{array}$ \\
& 29 & 04 & 00 & 01 \\
\hline rpoBMUT1 (D516V) & 01 & 00 & 00 & 00 \\
\hline rpoBMUT2A (H526Y) & 02 & 00 & 00 & 00 \\
\hline rpoBMUT2B(H526D) & 01 & 01 & 00 & 07 \\
\hline rpoMUT3(S531L) & 25 & & \\
\hline
\end{tabular}

Table.3 Missing wild type of probe for Isoniazid resistance. Total Isoniazid isolates (n-64)

\begin{tabular}{|l|l|l|l|}
\hline GENE & BAND MISSING & $\begin{array}{l}\text { WILD TYPE MISSING } \\
\text { WITH KNOWN MUTATION }\end{array}$ & $\begin{array}{l}\text { WILD TYPE MISSING } \\
\text { WITH NO MUTANT BAND }\end{array}$ \\
\hline KatG & WT & 42 & 02 \\
\hline inhA & WT1 & 09 & 02 \\
\hline & WT2 & 00 & 00 \\
\hline
\end{tabular}

Table.4 Mutation pattern in Isoniazid resistance. Total Isoniazid resistance isolates (n-64)

\begin{tabular}{|l|l|l|l|l|l|}
\hline MUTATION PRESENT & $\begin{array}{l}\text { IN MISSING } \\
\text { WILD TYPE } \\
\text { WITH KNOWN } \\
\text { MUTATION }\end{array}$ & $\begin{array}{l}\text { IN ONE OR } \\
\text { MORE WILD } \\
\text { TYPE BAND } \\
\text { MISSING } \\
\text { WITH } \\
\text { MUTANT } \\
\text { PRESENT }\end{array}$ & $\begin{array}{l}\text { IN ONE OR } \\
\text { MORE WILD } \\
\text { TYPE } \\
\text { MISSING } \\
\text { WITH NO } \\
\text { MUTANT } \\
\text { PROBE n-4 }\end{array}$ & $\begin{array}{l}\text { MIXED } \\
\text { ISONIAZID } \\
\text { RESISTANCE }\end{array}$ & $\begin{array}{l}\text { MUTATION } \\
\text { PRESENT IN } \\
\text { BOTH inhA } \\
\text { AND katG } \\
\text { GENE } \text { n-1 }\end{array}$ \\
\hline katGMUT1 (S315T1) & 42 & 00 & 00 & 06 & \\
\hline katGMUT 2 (S315T2) & 00 & 00 & 00 & 00 & 01 \\
\hline inhAMUT1 (C15T) & 09 & 00 & 00 & 02 & 00 \\
\hline inhAMUT 2 (A16G) & 00 & 00 & 00 & 00 & 01 \\
\hline inhAMUT 3A (T8C) & 00 & 00 & 00 & 00 & 00 \\
\hline inhA MUT 3B (T8A) & 00 & 00 & 00 & 00 & 00 \\
\hline
\end{tabular}


A comparison study between Xpert MTB/RIF with Line Probe Assay for rapid detection of Rifampicin Monoresistant Mycobacterium tuberculosis was done by Syed Beenish Rufai and et al., in October 2013. In a total of 405 sputum samples, 285 smear positive samples were subjected to LPA. 72(25.8\%) samples showed multidrug resistance, 62(22.2\%) showed Rifampicin monoresistance, 29 (10.3\%) showed Isoniazid monoresistance, Six $(2.1 \%)$ of the samples gave invalid results.

Of the 62 Rifampicin Mono resistant samples by LPA, 38 (61.4\%) showed Rifampicin resistance, while $21(33.8 \%)$ were found susceptible to Rifampicin by Xpert MTB. The MGIT960 results showed 100\% agreement with LPA results but only $64.4 \%$ agreement with Xpert MTB/RIF results. Sequencing analysis of discrepant samples showed $91.3 \%$ concordance with LPA but only $8.7 \%$ concordance with the Xpert MTB/RIF assay (10). These findings clearly indicate that more advancement have to be done in the case for Xpert MTB so that its sensitivity can be increased for rapid diagnosis.

Our area of concern is that Cases of pulmonary tuberculosis have been missed along with the case of MDR TB, and progression of disease from TB which can be cured in a period of 6-9 months to MDR TB which take upto 24 months to cure and the treatment course which also has many side effects is alarming. The reason of this progression is partly due to lack of infrastructure and failure to implement the policies.

According to National Strategic Plan 20122017 for TB, it has been decided to extend the reach of RNTCP services to peripheral regions to diagnose $\mathrm{TB}$ including $\mathrm{MDR} \mathrm{TB}$ and expanded its services for management of multidrug resistance TB. These targets can be achieved by rapid diagnosis of TB and drug susceptibility testing. ${ }^{2}$

Conventional drug susceptibility testing using solid media such as LJ media is time consuming, it takes upto 3 months. Liquid culture medium MGIT 960 are sensitive and faster (average time 14 days) ${ }^{7}$ for detection of MDR TB whereas Line Probe Assay have a rapid turnover time of 48-72 hours for detection of MDR TB. ${ }^{8}$

Line Probe Assay has also been approved by $\mathrm{WHO}^{8}$ for use in low income setting, so it can be used as rapid detection of MDR TB and common mutation for the resistance can be detected $^{9}$ and early treatment can be started.

After setting up of DST lab in Raichur Institute of Medical Sciences, Raichur Microbiology Department, Line Probe Assay could be very helpful for the detection of MDR TB in this North Karnataka region and will help to decrease the burden of TB on the society.

\section{References}

1. WHO | Tuberculosis [Internet]. WHO. [cited 2016 Sep 23]. Available from: http://www.who.int/mediacentre/factshee ts/fs104/en/

2. TB Facts $\mid$ TB, tests, drugs, statistics [Internet]. TB Facts.org.[cited 2016 Sep 23]. Available from: http://tbfacts.org/

3. Ramachandran R, Nalini S, Chandrasekar V, Dave PV, Sanghvi AS, Wares F, et al. Surveillance of drug-resistant tuberculosis in the state of Gujarat, India. Int J Tuberc Lung Dis. 2009 Sep;13(9):1154-60.

4. Hanif M, Malik S, Dhingra VK. Acquired drug resistance pattern in tuberculosis cases at the State 
Tuberculosis Centre, Delhi, India. Int $\mathbf{J}$ Tuberc Lung Dis. 2009 Jan;13(1):74-8.

5. Paramasivan CN, Rehman F, Wares F, Sundar Mohan N, Sundar S, Devi S, et al. First- and second-line drug resistance patterns among previously treated tuberculosis patients in India. Int $\mathbf{J}$ Tuberc Lung Dis. 2010 Feb;14(2):243-6.

6. Singhal R, Myneedu VP, Arora J, Singh N, Sah GC, Sarin R. Detection of multidrug resistance \& characterization of mutations in Mycobacterium tuberculosis isolates from North- Eastern States of India using GenoType MTBDRplus assay. Indian J Med Res. 2014 Oct;140(4):501-6.

7. Somoskövi A, Ködmön C, Lantos A, Bártfai Z, Tamási L, Füzy J, et al. Comparison of recoveries of mycobacterium tuberculosis using the automated BACTEC MGIT 960 system, the BACTEC 460 TB system, and Löwenstein-Jensen medium. J Clin Microbiol. 2000 Jun;38(6):2395-7.
8. World Health Organisation: Policy Statement. Molecular Line Probe Assays for Rapid Screening of patients at risk of multidrug resistant tuberculosis (MDRTB), 2008. Accessed 18 November 2000.

9. Brossier F, Veziris N, Truffot-Pernot C, Jarlier V, Sougakoff W. Performance of the genotype MTBDR line probe assay for detection of resistance to rifampin and isoniazid in strains of Mycobacterium tuberculosis with lowand high-level resistance. $\mathbf{J}$ Clin Microbiol. 2006 Oct; 44(10):3659-64.

10. Syed Beenish Rufai, Parveen Kumar, Amit Singh, Suneel Prajapati, Veena Balooni, and Sarman Singh. Comparison of Xpert MTB/RIF with Line Probe Assay for Detection of Rifampin-Monoresistant Mycobacterium tuberculosis. J Clin Microbiol. 2014 Jun; 52(6): 1846-1852.

\section{How to cite this article:}

Akshay Kumar Arya, R. Venkatesh Naik, K.V. Arjun and Peerapur, B.V. 2017. Detection of Multidrug Resistance and Characterization of Mutations in Mycobacterium tuberculosis Isolates in Raichur District. Int.J.Curr.Microbiol.App.Sci. 6(10): 1543-1549.

doi: https://doi.org/10.20546/ijcmas.2017.610.185 